\title{
Entry Mode Strategy and Firm Performance in Emerging Economy: Moderating Role of Organisational Structure and Environmental Turbulence
}

DOI: 10.7595/management.fon.2021.0012

\begin{abstract}
:
Research question: This study assessed the combined moderating effect of organizational structure and environmental turbulence on entry mode strategy - performance link focusing on baby care industry in Lagos State, Nigeria. Motivation: The manufacturers of baby care products in Nigeria have struggled to understand the complexities of entry mode strategy and how to use firm-specific capabilities to contain the threats from new entrants given the idiosyncrasies of the business environment in Nigeria. Also, considering the fast changing business environment and the need for firms to align internal organisational structure to manage the external environmental challenges, this study via the supposition of Hage (1965) axiomatic theory of organisations examined the joint moderating effect of organisational structure and environmental turbulence on entry mode strategy - performance linkage focusing on the baby care industry in Lagos State, Nigeria. Idea: Empirical submissions on the combined moderating effect of organizational structure and environmental turbulence on the interactions of entry mode strategy and organizational performance are sparse. Hence, this study addressed this gap in literature. Data: The survey research design and a sample of 518 employees engaged in FMCG manufacturers in Lagos State, Nigeria were adopted for this study. Tools: A validated structured questionnaire was the instrument of data collection for this study and the hierarchical regression analysis was adopted to test the hypotheses formulated. Findings: The results showed that the interaction between entry mode strategy and firm performance was positive and significant. Further analysis revealed that the interaction term of organizational structure and environmental turbulence accounted for the rise in firm performance to suggest that organizational structure and environmental turbulence are joint significant moderators. This suggests that entry mode strategy appropriateness is key to firm performance and that the fit between organisational structure and the macro-environment is a precondition to higher performance. Contribution: This study adds to recent empirical literature on the link between entry mode strategy, organizational structure, environmental turbulence, and firm performance within emerging economy context, and it provides additional support for the assumptions of the eclectic theory and Hage's axiomatic theory of organization.
\end{abstract}

Keywords: entry mode strategy, firm performance, organizational structure, environmental turbulence, eclectic theory, Hage axiomatic theory, emerging economy

JEL classification: F23, L10, M31

\section{Introduction}

Extant literature upholds that in today's highly competitive market, the desire for organisations to consistently achieve significant market performance is critical for firms' going concern (Anning-Dorson, 2018). The manufacturers of baby care products in Nigeria have struggled to understand the complexities of entry mode strategy and how to use firm-specific capabilities to contain the threats from new entrants given the idiosyncrasies of the business environment in Nigeria (Euromonitor International, 2018); that is an economy that has transitioned from a low-income to a mid-income and towards an emerging economy within the Middle-East and Africa region. Hence, the performance of these manufacturers as reported by their respective yearly financial 
statements suggested a downward trend in performance (Frieslandcampina, 2017; Procter \& Gamble, 2018; PZ Cussion, 2018; Unilevel Nigeria, 2018). Corroborating this narrative was the Euromonitor International report on infant care products in Nigeria (2019) that stressed that the penetration of these infant specific products in Nigeria is quite low and the category is still quite far from reaching its full market potential.

Perchance, the manufacturers' weak capabilities to respond adequately to new competitors, and their not being able to effectively address the several challenges in the Nigeria's business climate may have resulted in the low performance of players in the baby care industry (Onamusi, 2020). Another course of concern is the attendant consequence of the coronavirus pandemic which to a large extent resulted in economy lockdowns, factory shutdowns, production restricted, revenue and job loss, to mention a few. Scholars have examined issues bordering on entry mode strategy choice and on which factors determine the entry mode strategy in a different research context and adopted an array of methodologies (Dahms, 2017; Lai, Lin, \& Chen 2017; Onamusi, 2020; Schu \& Morschett, 2017; Yasmeen \& Viswanathan, 2017); nevertheless, only a handful substantiated the entry mode strategy - performance linkage (Arasa \& Gideon, 2015; Brouthers, 2013; Hollender, Zapkau, \& Schwens, 2017; Nisar, Boateng, \& Wu, 2018; Onamusi, 2020; Teng, Huang, \& Pan, 2017) in the developed and emerging economies contexts. The validity of their findings is not doubtful; nonetheless, the differences in research settings and the problem identified may suggest a diverse result, hence suggesting a need for this study. For example, Onamusi (2020) has considered the performance-effect of entry mode strategy and the relevance of customer engagement in enhancing how new firms can enter a foreign market and achieve higher performance, however, the study did not consider the effect of changing environment (environmental turbulence) nor did it evaluate the relevance of organisational structure in managing the changing environment, and how both moderate the entry mode strategy - performance link.

Given the fast-changing business environment and the need for firms to align internal organisational structure to manage the external environmental challenges, this study equally assessed the issue of under what conditions firms can achieve improvement in performance within an emerging economy's context. Hage (1965) axiomatic theory of organisations provide a theoretical explanation for how a firm can achieve this. According to Hage (1965) an alignment between a firm's organisational structure and the environment is a precondition for improved market performance. What the scholar advocates through this theory of organisational theory is that the structure of an organisation is environment specific. For example, an organic structure will work better in a turbulent environment, while the mechanistic structure will achieve better performance for firms that operate in a stable environment. However, empirical submissions on the combined effect of organisational structure and environmental turbulence on the interactions of entry-mode strategy and organisational performance are sparse. This may be because scholars have no reason(s) to combine two seemingly different business environment parameters, one within the internal environment (organisational structure) and the other external environment (environmental turbulence) to moderate the interactions proposed in this study. Hence, this presents another gap worthy of study. Given this discussion, this study addressed the question of what is the combined moderating effect of organisational structure and environmental turbulence on entry mode strategy - performance linkage focusing on the baby care industry in Lagos State, Nigeria?

\section{Literature Review}

\subsection{Theory and rationale for hypotheses formulated}

This study adopted the eclectic theory (Dunning, 2000) and Hage axiomatic theory (1965) to substantiate the interactions between entry mode strategy, organisational structure, environmental turbulence, and firm performance.

First, the eclectic theory is a valuable theory propounded by Dunning to provide theoretical explanation for how firms can engage in international business and achieve significant performance through ownership, location, and internalization framework. Achieving competitive advantage for a firm seeking cross-border engagement, can be done by possessing critical resources, identifying business locations where such firm can significantly access cheap factors of production, and where the firm can produce its market offering within its operations as against engaging third parties to do so (Dunning, 2000). These forms the basis for choosing an appropriate entry strategy that commands superior firm performance.

Second, the Hage axiomatic theory of organisation provided theoretical justification for the moderation interaction examined. Hage (1965) suggested that organisation seeking to achieve significant progress should ensure an alignment between two seemingly different environmental factors; internal and external. Firms who possess the ambidextrous capability will achieve superior performance. Hence given the submission 
of these two theories, this study posited that; entry mode strategy would have significant effect on firm performance $\left(\mathrm{H}_{01}\right)$, more so, an alignment between organisational structure, and environmental turbulence would have significant combined moderating effect on the interaction between entry mode strategy and organisational performance $\left(\mathrm{H}_{02}\right)$.

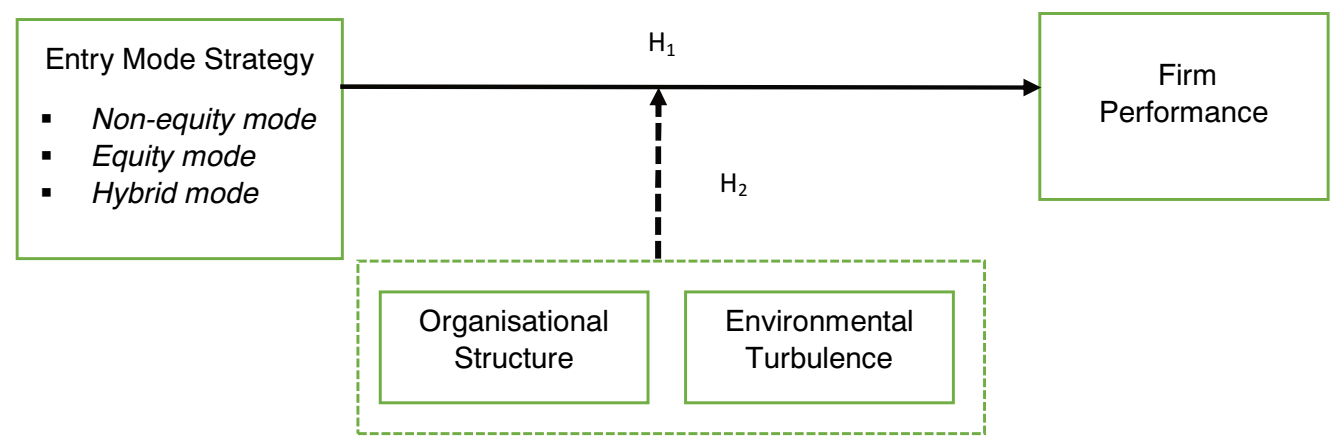

Figure 1: Conceptual Model:

Source: Researcher's Conceptual Model

\subsection{Empirical review}

\section{Moderating effect of organisational structure and environmental turbulence on entry mode strategy - performance linkage}

The few empirical studies conducted to substantiate entry mode strategy - performance linkage provided mixed results; perhaps the contextual differences, the study settings, unit of analysis, and the overall method employed in these studies (which vary) may have accounted for the divergence in findings. For instance, Onamusi (2020) suggested that entry mode strategy explained significant variation in firm performance. Similarly, Acheamponga and Kumahb (2012) established a link between the market entry strategy and perceived performance for multinational service firms in Ghana. The scholars emphasised that entry strategies adopted by these firms explained positive and significant contribution to organisational performance. Although the research context for both Acheamponga and Kumahb (2012) and Onamusi (2020) differs as the latter focused on manufacturing companies in Nigeria while the former examined the service industry in Ghana, both studies substantiated the performance effect of choosing an appropriate entry mode strategy for organisations. In a related study in Kenya, non-equity (licensing) and equity mode (direct investment) strategies were found to explain a significant variation in firm performance.

In a meta-analysis of entry mode between 1980 and 2010 conducted by Giachetti, Manzi, \& Colapinto (2019), they found out that organisations that adopted the higher-control in terms of ownership of the means of production in developing economies achieved higher organisational performance more than other entry mode strategy such as non-equity mode strategy. This finding was corroborated by Onamusi (2020) given that the hybrid mode strategy presented higher profit margin than other modes there by stressing the significance of entry mode strategy appropriateness for superior performance. Authors who share similar outcomes with Giachetti et al. (2019) and Onamusi (2020), included Awolusi (2013) and Brouthers (2013). Contrary to the findings established by Acheamponga and Kumahb (2012), Giachetti et al. (2019), and Onamusi (2020), Hofer and Baba (2018) found that equity and non-equity strategies had positive and statistically significant effect on small and midsized enterprises' performance. Also, some studies could not find any link between non-equity and firm performance (Brouthers \& Nakos, 2004; Hollender et al., 2017).

As regards the combined moderating effect of organisational sStructure and environmental Turbulence on the interaction between entry mode strategy and firm performance, there are studies written on the performance effect of organisational structure (Al-Qatawneh, 2014; Nwonu, Agbaeze, \& Obi-Anike, 2017), and how environmental turbulence influence organisational performance (Onamusi, Asikhia, \& Makinde, 2019; Zaidi \& Othman, 2015). However, studies that emphasised the joint moderating effect of both variables on the independent - dependent interactions under investigation are sparse. This may be because scholars may have no reason(s) to combine two seemingly different business environment parameters, one within the internal environment (organisational structure) and the other external environment (environmental turbulence) to moderate the interactions proposed in this study. Moreover, the empirical discussions on entrymode strategy so far in this study did not consider this objective mainly because the issues investigated in their studies differ when compared to this study. 
In this situation, a theoretical explanation will be employed to position the possible interaction effect to be expected. According to the axiomatic theory of organisations, Hage (1965) suggested that alignment between a firm's organisational structure and the environment is a precondition for improved performance. What the scholar advocated through his theory of organisational theory is that the structure of an organisation is environment specific. For example, an organic structure will work better in a turbulent environment, while the mechanistic structure will achieve better performance in firms that operate in a stable environment. To buttress Hage (1965) assumptions, the contingency theory of fit-as-a-moderator equally strengthened this discussion in the sense that both organisational structure and environmental turbulence act as contextual moderators. Precisely when the interactions between the independent and the dependent variables are enhanced as a result of a third variable effect than the contingency theory holds.

\section{Methodology}

\section{Context, data collection, measurement of variable, and analytical techniques}

The study adopted the survey research design with a population of 8,452 employees of FMCG baby care category. A sample size of 518 was scientifically determined using the Research Advisor. The stratified random sampling techniques were adopted to select employees from each management levels to aid faithful representation. In line with the survey research, a structured questionnaire was used for data collection because it offered an opportunity to collect the perceptions of respondents on issues under investigation. The questionnaire items were adapted from prior studies and they followed the Likert type scale. After administering the 518 questionnaires during office hours in respective firms, they were collected, sorted and screened. The study achieved a response rate of $87.2 \%$.

In this study the dependent variable is the firm performance, the independent variable is the entry mode strategy, and the moderating variables are the organisational structure and the environmental turbulence. These variables are discussed taking into consideration their measures in previous studies. A prior study adopted a multi-item scale to measure the firm performance (Asikhia, Makinde, \& Onamusi, 2020; Bendig, Enke, Thieme, \& Brettel, 2018; Vij \& Bedi, 2016). The studies encourage the use of financial and non-financial measures because of the inherent weakness, in the use of one only. Hence, to capture the complete picture with respect to performance, it became imperative to use the two organisational performance measures. As identified in earlier studies, the entry mode strategy is conceptualized as a categorical variable which includes: equity mode, non-equity mode, and hybrid mode (Lin \& Ho, 2019; Onamusi, 2020).

The organisational structure acts as a circumstantial moderator that determines the extent to which the entry mode strategy influences organisational performance. It is measured as an organistic structure by prior scholars (Covin \& Slevin, 1988; Wilden, Gudergan, Nielsen, \& Lings, 2013) using a Likert type scale. Environmental turbulence equally acts as a moderator that affects how the entry mode strategy and firm-level capability influence the firm performance. It reflects the extent of changes experienced in a firm's macro environment which presents both threats and opportunities (Dess \& Beard, 1984; Jaworski \& Kohli, 1993). Both scholars employed a Likert type scale to measure environmental turbulence. Overall, this study follows a similar approach adopted by these prior studies to measure all the variables identified in this study.

The study employed a hierarchical regression analysis to establish the combined moderating effect of organisational structure and environmental turbulence on the functional relationship between the entry mode strategy and organisational performance.

\section{Analysis and Results}

Table 1: Validity and Reliability Test Result

\begin{tabular}{|l|l|c|c|c|}
\hline S/N & \multicolumn{1}{|c|}{ Variables } & $\begin{array}{c}\text { Cronbach's Alpha } \\
\text { Co-efficient }\end{array}$ & Composite Reliability & AVE \\
\hline 1 & Organisational Structure & 0.814 & 0.882 & 0.570 \\
2 & Environmental Turbulence & 0.808 & 0.860 & 0.607 \\
3 & Firm Performance & 0.891 & 0.913 & 0.629 \\
\hline
\end{tabular}

Source: Researcher's Results 
Table 1 presents the result of the factor analysis and the reliability statistics for the questionnaire used in this study. This was done to show that the instrument is valid and reliable. Hence the AVE value of above 0.50 and a Cronbach's Alpha coefficient of above 0.70 suggest that the instrument is valid and reliable for this study.

Table 2: Summary of Hierarchical Regression Analysis for the Moderating effect of Organisational Structure and Environmental Turbulence on Entry Mode Strategy - performance Linkage

\begin{tabular}{|c|c|c|c|c|c|c|c|c|c|}
\hline Model $^{1,2,3}$ & Beta & $\mathbf{t}$ & Sig. & $\mathbf{R}$ & $\mathbf{R}^{2}$ & Adj. $R^{2}$ & $\Delta \mathbf{R}^{2}$ & $\Delta \mathbf{F}$ & $\begin{array}{l}\text { Sig. F } \\
\text { Change }\end{array}$ \\
\hline${\text { (Constant })^{1}}^{1}$ & 4.681 & 137.077 & .000 & $.291^{\mathrm{a}}$ & .085 & .080 & .085 & 20.724 & .000 \\
\hline Non-equity mode & .244 & 3.972 & .000 & & & & & & \\
\hline Equity mode & .303 & 6.215 & .000 & & & & & & \\
\hline \multicolumn{10}{|c|}{ F \& Anova Sig: $20.724(2,449), p=.000$} \\
\hline$(\text { Constant })^{2}$ & 3.130 & 22.757 & .000 & $.545^{\mathrm{b}}$ & .297 & .290 & .212 & 67.419 & .000 \\
\hline Non-equity mode & .313 & 5.797 & .000 & & & & & & \\
\hline Equity mode & .119 & 2.511 & .012 & & & & & & \\
\hline Organisational structure & .192 & 3.437 & .001 & & & & & & \\
\hline $\begin{array}{l}\text { Environmental } \\
\text { Turbulence }\end{array}$ & .414 & 8.504 & .000 & & & & & & \\
\hline \multicolumn{10}{|c|}{ F \& Anova Sig: $47.137(4,447), p=.000$} \\
\hline (Constant) $^{3}$ & 2.192 & 11.061 & .000 & $.596^{c}$ & .355 & .348 & .058 & 40.198 & .000 \\
\hline Non-equity mode & .977 & 8.365 & .000 & & & & & & \\
\hline Equity mode & 1.113 & 6.818 & .000 & & & & & & \\
\hline Organisational structure & .554 & 7.079 & .000 & & & & & & \\
\hline $\begin{array}{l}\text { Environmental } \\
\text { Turbulence }\end{array}$ & .489 & 10.144 & .000 & & & & & & \\
\hline EMS*OS*ET & -1.044 & -6.340 & .000 & & & & & & \\
\hline
\end{tabular}

a. Predictors: (Constant), Entry-Mode Strategy *Hybrid strategy is the reference category b.Predictors: (Constant), Entry-Mode Strategy, organisational structure, Environmental turbulence c. Predictors: (Constant), Entry-Mode Strategy, organisational structure, Environmental turbulence, EMS*OS*ET denote Entry-Mode Strategy* organisational structure * Environmental turbulence d. Outcome Variable: Organisational Performance Source: Researcher's Field Survey Results

Table 2 presents hierarchical multiple regression results for the combined moderating effect of organisational structure and environmental turbulence on the effect of the entry mode strategy on organisational performance. In model one, entry mode strategy - performance link was examined. The second model examined the effect of the entry mode strategy, organisational structure, and environmental turbulence on organisational performance. In the third model, the combined moderating effect of organisational structure and environmental turbulence on the entry mode strategy - performance linkage was examined and discussed accordingly.

In the first model, the entry mode strategy explained $8 \%$ of the changes experienced in organisational performance $\left(\mathrm{R}=0.291\right.$, Adj. $\left.R^{2}=0.080, F(2,449)=20.724, \mathrm{p}=0.000\right)$. In the second model, the entry mode strategy, organisational structure and environmental turbulence explained $29 \%$ variation in organisational performance $\left(\right.$ Adj. $\left.\mathrm{R}^{2}=0.290, F(4,447)=47.137, \mathrm{p}=.000\right)$. In the third model, when the interaction term of entry mode strategy, organisational structure, and environmental turbulence were considered, it had a concomitant increase in organisational performance by $5.8 \%\left(\Delta R^{2}=0.058, \Delta F=40.198, \mathrm{P}=0.000\right)$ because 
$\mathrm{R}^{2}$ increased from 0.085 (in model one) to 0.355 (in model three). This result shows that organisational structure and environmental turbulence has significant joint moderating effect on the interaction between the entry mode strategy and the organisational performance.

\section{Conclusion}

Conceptually, scholars have opined that organisational structure is a precondition for achieving organisational goals. According to Gurianova, Gurianov, and Mechtcheriakova (2014), OS is a construct which assists with the actualisation of effective decision making. Similarly, but from a social networking context, Islam, Jasimuddin, and Hasan (2015) viewed OS as a system that governs communication patterns and interaction within an organisation, such that some standardised procedures and controls which improve organisational performance can be formulated over time. On the part of Al-Qatawneh (2014, p. 231), OS "is a method by which organisational activities are divided, organised, and coordinated", hence implying that organisational structure provides the template for coordinating work activities within an organisation to achieve desirable objectives (Alande, 2013). Similarly to other scholars such as Gurianova et al. (2014), Islam et al. (2015) and Alande (2013), Wilden et al. (2013) pointed out that organisational structure is a circumstantial moderator that determines the degree to which a firm achieves a fit and align itself to achieve significant results in a dynamic environment.

Furthermore, environmental turbulence presents uncertain consequences for business firms. While its ripple effects may offer agile firms the opportunity and potentials for growth, the risks and challenges presented by the unpredictability of a turbulent environment are of concern to every firm in emerging economy, because managers are unable to make a reasonable long-time plan and make predictions that can aid performance (Dess \& Beard, 1984). The narrative suggest that environmental turbulence could have both positive and negative effects for a firm operating within its scope. The Hage (1965) axiomatic theory suggested a basis for a link between organisational structure and the macro environment. According to Hage (1965) the fit between a firm's organisational structure and the macro environment is a precondition for improved performance.

These findings regarding the presence of a joint moderating effect of organisational structure and environmental turbulence on entry mode strategy - performance linkage, is supported by scholars. The finding aligns with the Hage axiomatic theory of organizations. According to Hage (1965), the fit between a firm's organisational structure and the macro environment is a precondition for improved performance. Hage (1965) submission was corroborated by Linton and Lask (2017). The scholars opined that an appropriate blend of internal - external organisational factors potentially enhances achieving competitive advantage. To buttress Linton and Lask (2017) assertion and Hage's (1965) assumptions and learn support for this study's outcomes, the contingency theory of fit-as-a-moderator equally comes to bear. According to the contingency narratives, both organisational structure and environmental turbulence act as contextual moderators. Precisely when the interactions between the independent (entry mode strategy) and the dependent variable (organisational performance) is enhanced as a result of a third variable (organisational structure*environmental turbulence), then the contingency theory holds.

On the contrary, scholars have criticised the bases for this moderation (interaction) perspective. According to Van de Ven, et al. (2013), the desire to accomplish internal and external alignment remains an obscure objective, especially for firms that operate within an environment that has several conflicting demands and for firms that have issues with internal organisation trade-offs and high performance target. Accordingly, Van de Van et al. (2013) argue further that in a scenario like this, it is exceptionally challenging to conceptualize a theoretical answer. Furthermore, there comes the Configuration theorist. The Configuration theorist believes that it is not practicable for firms to align entirely with their contingencies, considering that as the firm is adapting its structure to fit the contingent factors, the factors themselves continue to change, hence, the issue of fit does not materialise. Despite the criticism, the study yet offers significant implication for the management of the manufacturers operating within an emerging economy. Given these findings, the managements of the selected companies need to adopt an appropriate entry mode strategy, and adopt measures that guarantee a robust fit between their companies' organisational structure and the macro-environment; this, according to the axiomatic theory, is a precondition for higher performance.

\section{REFERENCES}

[1] Acheamponga, G., \& Kumah, B. (2012). Impact of firm-level factors and market entry mode on performance: A study of service MNCs in an emerging economy. Management Science Letters, 2(2), 631-646. doi:10.5267/j.msl.2011.11.004

[2] Alande, J. O. (2013). Role of human resource management in devolution of counties in Kenya. SCP, 21(6), 588-598.

[3] Al-Qatawneh, M. I. (2014). The impact of organisational structure on organisational commitment: A comparison between public and private sector firms in Jordan. European Journal of Business and Management, 6(12), 30-37. 
[4] Anning-Dorson, T. (2018). Customer involvement capability and service firm performance: The mediating role of innovation. Journal of Business Research, 86, 269-280. DOI:10.1016/j.jbusres.2017.07.015

[5] Arasa. R., \& Gideon, L. N. (2015). The influence of international market entry strategies on firm financial performance: A study of the manufacturing multinationals in Kenya. International Journal of Economics, Commerce and Management United Kingdom, 3(9), 332-349.

[6] Asihkia, O. U., Makinde, G. O., \& Onamusi, A. B. (2020). Marketing capability and firm performance: Mediating role of new product development and management innovation. The International Journal of Business \& Management, 8(2), 69-77. DOI:10.24940/theijbm/2020/v8/i2/bm2002-033

[7] Awolusi, O. D. (2013). Factors influencing the internationalisation of Nigerian manufacturing firms: An empirical analysis. International Journal of Business and Management Review, 1 (3), 14-34.

[8] Bendig, D., Enke, S., Thieme, N., \& Brettel, M. (2018). Performance implications of cross-functional coopetition in new product development: The mediating role of organizational learning. Industrial Marketing Management. DOI:10.1016/j.indmarman.2018.02.007

[9] Brouthers, K. D., \& Nakos, G. (2004). SME entry mode choice and performance: A transaction cost perspective. Entrepreneurship Theory and Practice, 28(3), 229-247. DOI:10.1111/j.1540-6520.2004.00041.x

[10] Brouthers, K. D. (2013). Institutional, cultural and transaction cost influences on entry mode choice and performance. Journal of International Business Studies, 44(1), 1-13. DOI:10.1057/jibs.2012.22

[11] Covin, J. G., \& Slevin, D. P. (1988). The influence of organization structure on the utility of an entrepreneurial top management style. Journal of Management Studies, 25(3), 217-234. DOI:10.1111/j.14676486.1988.tb00033.x

[12] Dahms, S. (2017). Determinants of foreign-owned subsidiary performance in emerging economies. Management Research Review, 40(6), 626-647. DOI:10.1108/mrr-03-2016-0057

[13] Dess, G. G., \& Beard, D. W. (1984). Dimensions of organizational task environments. Administrative Science Quarterly, 29(1), 52. DOI:10.2307/2393080

[14] Dunning, J. H. (2000). The eclectic paradigm as an envelope for economic and business theories of MNE activity. International Business Review, 9(2), 163-190. DOI:10.1016/s0969-5931(99)00035-9

[15] Euromonitor International. (2019). Baby and child-specific product in Nigeria. Retrieved from Euromonitor International Passport website: http://www. Euromonitor International.com

[16] Euromonitor International. (2018). Baby food in Nigeria. Retrieved from Euromonitor International Passport website:

[17] FrieslandCampina Wamco Nig. (2019). Historical background. Retrieved from Friesland Campina Wamco Nig. website: http://www.frieslandcampinawamco.ng.com

[18] Giachetti, C., Manzi, G., \& Colapinto, C. (2019). Entry mode degree of control, firm performance and host country institutional development: A meta-analysis. Management International Review, 59(1), 339.

[19] Gurianova, E., N Gurianov, I., \& A Mechtcheriakova, S. (2014). The influence of phase the organizational life cycle on organizational structure management and transaction costs. Asian Social Science, 10(20). DOI:10.5539/ass.v10n20p137

[20] Hage, J. (1965). An axiomatic theory of organisations. Administrative Science Quarterly, 10(3), 289-299. DOI:10.2307/2391470

[21] Hofer, K. M., \& Baba, A. (2018). Market Entry Strategies, Innovation and Performance of SMEs in the Service Sector. In Key Success Factors of SME Internationalisation: A Cross-Country Perspective. Emerald Publishing Limited.

[22] Hollender, L., Zapkau, F. B., \& Schwens, C. (2017). SME foreign market entry mode choice and foreign venture performance: The moderating effect of international experience and product adaptation. International Business Review, 26(2), 250-263. DOI:10.1016/j.ibusrev.2016.07.003

[23] Islam, M. Z., Jasimuddin, S. M., \& Hasan, I. (2015). Organizational culture, structure, technology infrastructure and knowledge sharing. VINE, 45(1), 67-88. DOI:10.1108/vine-05-2014-0037

[24] Jaworski, B. J., \& Kohli, A. K. (1993). Market orientation: Antecedents and consequences. Journal of Marketing, 57(3), 53. DOI:10.2307/1251854

[25] Lai, J., Lin, W., \& Chen, L. (2017). The influence of CEO overconfidence on ownership choice in foreign market entry decisions. International Business Review, 26(4), 774-785. DOI:10.1016/j.ibusrev.2017.01.006

[26] Lin, F., \& Ho, C. (2019). The knowledge of entry mode decision for small and medium enterprises. Journal of Innovation \& Knowledge, 4(1), 32-37. DOl:10.1016/j.jik.2018.02.001

[27] Linton, G., \& Kask, J. (2017). Configurations of entrepreneurial orientation and competitive strategy for high performance. Journal of Business Research, 70(6), 168-176. DOI:10.1016/j.jbusres.2016.08.022

[28] Nisar, S., Boateng, A., \& Wu, J. (2018). The entry mode strategy and performance of SMEs: Evidence from Norway. Research in International Business and Finance, 45, 323-333. DOI:10.1016/j.ribaf.2017.07.164 
[29] Nwonu, C. O., Agbaeze, E. K., \& Obi-Anike, H. O. (2017). Effect of organisational structure on performance of selected manufacturing companies in Enugu state Nigeria. The International Journal of Business \& Management, 5(5), 190-206.

[30] Onamusi, A. B., Asikhia, O. U., \& Makinde, G. O. (2019). Environmental munificence and service firm performance: The moderating role of management innovation capability. Business Management Dynamics, 6(9), 13-25.

[31] Onamusi, A. B. (2020). Entry mode strategy, customer engagement and firm performance. Journal of Business and Social Review in Emerging Economies, 6(1), 99-112. DOI:10.26710/jbsee.v6i1.866

[32] Procter \& Gamble Press Release. (July, 2018). Procter \& Gamble closes its Agbara plant [Web log post]. Retrieved from

[33] PZ Cusson Nig. Plc. (2019). Press release on decreasing exposure to the Nigeria market. Retrieved from PZ Cusson Nigeria website:

[34] Schu, M., \& Morschett, D. (2017). Foreign market selection of online retailers- A path-dependent perspective on influence factors. International Business Review, 26(4), 710-723. DOI:10.1016/j.ibusrev.2017.01.001

[35] Teng, L., Huang, D., \& Pan, Y. (2017). The performance of MNE subsidiaries in China: Does it matter to be close to the political or business hub? Journal of International Management, 23(3), 292-305. DOI:10.1016/j.intman.2016.12.002

[36] Unilever unaudited financial report (2018). Retrieved from unilever Nigeria website:

[37] Van de Ven, A. H., Ganco, M., \& Hinings, C. R. (2013). Returning to the frontier of contingency theory of organizational and institutional designs. Academy of Management Annals, 7(1), 393-440. DOI:10.5465/19416520.2013.774981

[38] Vij, S., \& Bedi, H. S. (2016). Are subjective business performance measures justified? International Journal of Productivity and Performance Management, 65(5), 603-621. DOI:10.1108/ijppm-12-2014-0196

[39] Wilden, R., Gudergan, S. P., Nielsen, B. B., \& Lings, I. (2013). Dynamic capabilities and performance: Strategy, structure and environment. Long Range Planning, 46(1-2), 72-96. DOI:10.1016/j.Irp.2012.12.001

[40] Yasmeen, K., \& Viswanathan, K. (2017). Influence of country factors on entry-mode through knowledge and transactional cost economics: Market entry evidence from construction firms. International Journal of Economics and Financial Issues, 7(3), 581-585.

[41] Zaidi, M. F., \& Othman, S. N. (2015). Organisational capabilities, environmental turbulence, and NPD performance: A study on Malaysian manufacturing firms. Procedia - Social and Behavioral Sciences, 172, 286-293. DOI:10.1016/j.sbspro.2015.01.366

Received: 2020-07-26

Revisions requested: $2020-12-19$

Revised: 2021-01-01 (3 revisions)

Accepted: 2021-02-10

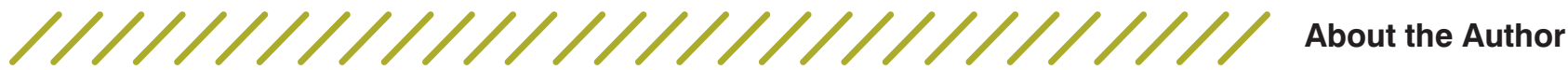

Abiodun Babatunde Onamusi

Lead City University, Department of Management \& Accounting, Ibadan, Oyo State, Nigeria

Onamusi.abiodun@Icu.edu.ng

Abiodun Babatunde Onamusi, Ph.D., is a lecturer at the Department of Management and Accounting Lead City University Ibadan, Nigeria. He holds a Ph.D. degree from Babcock University Nigeria in Business Administration and possesses specialization in accounting, international business, and strategic management.

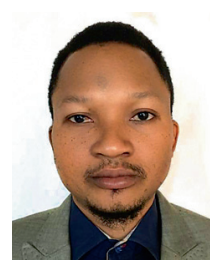

$\mathrm{He}$ is actively involved in Post-graduate studies in teaching, research, and mentorship at Lead City University. His research interest includes Merger \& Acquisition,

internationalization of firms, Leadership, Organization learning, Baby-care industry, Marketing, and Entrepreneurship and he is a small business consultant. 